\title{
RUANG HIJAU ALTERNATIF PADEMANGAN
}

\author{
Teresa Natalia ${ }^{1)}$, Dewi Ratnaningrum ${ }^{21}$ \\ 1)Program Studi S1 Arsitektur, Fakultas Teknik, Universitas Tarumanagara, teresanatalia98@gmail.com \\ 2)Program Studi S1 Arsitektur, Fakultas Teknik, Universitas Tarumanagara, dewir@ft.untar.ac.id
}

\begin{abstract}
Abstrak
Ray Oldenburg, dalam bukunya yang berjudul "The Great Good Places" menawarkan sebuah konsep ruang ketiga, di mana seseorang dapat menemukan zona nyamannya di luar dari rumah (first place) dan tempat kerja (second place). Namun, sayangnya, saat ini third place belum menjadi bagian dari seluruh masyarakat, padahal third place memungkinkan seseorang untuk beristirahat sejenak dan bersosialisasi dengan sesama. Ruang Hijau Alternatif Pademangan merupakan sebuah wadah yang berusaha menjawab kebutuhan dan ketertarikan masyarakat dalam kehidupan sehari-hari di mana pengunjung tidak hanya dapat berinteraksi satu dengan yang lain tetapi juga dapat berinteraksi dengan 'unsur hijau'. Kurangnya ruang terbuka hijau, banyaknya potensi kegiatan di dalam masyarakat, serta penggunaan ruang jalan sebagai ruang publik adalah beberapa alasan yang melatarbelakangi proyek ini. Berdasarkan hasil survey lapangan dan analisis kawasan, proyek ini berusaha untuk menjadi third place yang yang dapat dimanfaatkan baik secara individual maupun komunal. Terlepas dari fokus utamanya yang tertuju pada masyarakat sekitar, proyek ini juga terbuka untuk umum dan memungkinkan untuk pengunjung dari luar kawasan, menjadikannya sebuah tempat yang mampu menciptakan interaksi sekaligus memberikan kenyamanan bagi pengunjungnya. Dengan konsep bangunan yang ringan dan transparan, dan dengan metode critical regionalism yang berusaha menjawab kebutuhan kawasan, proyek ini berusaha untuk menjadi tempat yang dapat memberikan kesan lega dan menjadi tempat yang dapat diandalkan masyarakat setempat untuk beristirahat.
\end{abstract}

Kata Kunci: hijau; pademangan; ruang ketiga

\begin{abstract}
Ray Oldenburg, in his book entitled "The Great Good Places" explains a concept of initial space, by which one can find comfort aside from the house (first place) and workplace (second place). Unfortunately, these days, this concept of place are not familiar within the community. Alternative Green Space of Pademangan is a place which accommodates the needs and interests of the community in daily life from where visitors can interact with others in a natural environment. Lacking in open space, various potential activities by the community, and the use of road as a public space are some of the reasons behind this project. Based on field study and regional analysis, this project seeks to become a third place that provides individually and communally. Regardless to it main focus on the surrounding community, this project also opens to public and allows visitors from outside the region, making it a comfortable place to socialized. Aiming to create a light and transparent building, and with the method of critical regionalism that responds to the region, this project attempts to create a spacious place and safe haven for visitors.
\end{abstract}

Keywords: green; pademangan; third Place 


\section{PENDAHULUAN}

\section{Latar Belakang}

Saat ini, rumah menjadi salah satu tempat untuk mengisolasi diri. Interaksi masyarakat hanya bergantung pada first place sebagai tempat tinggal dan second place sebagai tempat kerja. Ray Oldenburg, dalam bukunya yang berjudul "The Great Good Places" menawarkan sebuah konsep third place, di mana seseorang dapat menemukan zona nyamannya di luar dari rumah dan tempat kerja. Di tempat ini, mereka dapat bersosialisasi, bertemu dengan orang baru, ataupun dapat menciptakan ruang bagi diri sendiri tanpa merasa terasing. Namun, tidak semua orang dapat menemukan third place-nya sendiri, dalam bentuk wadah yang nyaman dan layak.

Kawasan yang padat dan lahan yang terbatas pada akhirnya tidak memungkinkan untuk menciptakan tempat yang bisa dikunjungi semua orang tanpa bersifat komersil. Hal ini lah yang menyebabkan masyarakat Jakarta, terutama mereka yang merupakan kalangan menengah ke bawah, tidak dapat menemukan third place mereka sendiri dalam bentuk sebuah ruang publik yang nyaman dan layak, seperti yang terjadi pada masyarakat di Kelurahan Pademangan Barat.

Kelurahan Pademangan Barat secara umum didominasi oleh permukiman penduduk. Hal ini pada akhirnya menyebabkan keterbatasannya lahan sehingga minim ruang terbuka hijau. Padahal, masyarakat di kelurahan ini memiliki tingkat interaksi yang cukup tinggi satu dengan yang lain, mengingat banyaknya gang-gang kecil sehingga masyarakat sudah terbiasa berjalan kaki dalam aktivitas sehari-hari. Oleh karena itu, Pademangan membutuhkan sebuah third place yang dapat dikunjungi kapan saja dan sesuai dengan ketertarikan serta kebutuhan masyarakat, sehingga memberikan dampak positif bagi masyarakat.

\section{Rumusan Permasalahan}

a. Masyarakat setempat tidak memiliki ruang publik bersama, mengingat padatnya perumahan di kelurahan ini. Hal ini mendorong pemanfaatan jalan menjadi ruang publik bagi masyarakat setempat.

b. Anak-anak tidak mempunyai tempat bermain yang memadai, padahal banyak anak di kelurahan ini yang bermain di luar rumah setelah jam pulang sekolah.

c. Banyaknya masyarakat yang berdagang di dalam gang-gang sempit yang terdapat di dalam kawasan.

\section{Tujuan}

a. Mewadahi aktivitas masyarakat sesuai kebutuhan dan aktivitas yang sudah ada di dalam masyarakat Pademangan, salah satunya dengan menggantikan fungsi jalan sebagai ruang publik.

b. Mempermudah masyarakat dalam mencari tempat untuk beristirahat sejenak dari rutinitas keseharian sebagai third place dengan unsur hijau menjadi fokus utama.

c. Mewadahi potensi kegiatan masyarakat dalam bentuk penghijauan dan berdagang dalam bidang kuliner.

\section{KAJIAN LITERATUR}

\section{"The Great Good Places" oleh Ray Oldenburg}

Oldenburg (1997) dalam bukunya yang berjudul "The Great Good Places" menawarkan sebuah konsep third place, dimana seseorang dapat menemukan zona nyamannya di luar dari rumah (first place) dan tempat kerja (second place). Di tempat ini, mereka dapat bersosialisasi, bertemu dengan orang baru, ataupun dapat menciptakan ruang bagi diri sendiri tanpa merasa terasing. Ray Oldenburg mengutarakan beberapa karakteristik dari third place, yaitu; 
a. Neutral ground

Pengunjung boleh datang dan pergi sesuai dengan keinginan. Tempat ini tidak dimiliki oleh siapapun, sekaligus memberikan kesan yang nyaman seperti di rumah.

b. Leveler (a leveling place)

Setiap orang yang datang tidak dibatasi berdasarkan status, jabatan, ataupun usia. Semua orang dianggap sejajar. Selain itu, tempat ini juga bersifat inklusif, yang dapat dikunjungi oleh siapapun.

c. Conversation is the main activity

Aktivitas utama dalam third place ini ialah berkomunikasi dengan sesama dengan tujuan bersosialisasi dan berinteraksi antar individu.

d. Accessibility \& Accomodation

Mudah diakses dan dijangkau pengunjung, dimana tempat ini dapat dijangkau baik di pagi ataupun malam hari.

e. The regulars

Third place pada dasarnya membutuhkan orang-orang sebagai pengunjung tetap (the regulars). Setiap pengunjung baru dapat pula disebut sebagai the regulars, sehingga dibutuhkan kesan penerimaan untuk siapa saja yang datang ke tempat ini.

f. A Low Profile

Bangunan bersifat umum dan biasa, dalam hal ini dari segi ekspresi bangunan. Bangunan ini tidak berusaha untuk memukau dan tampil berbeda dari lingkungannya.

g. The mood is playful

Kesan playful ini dibutuhkan untuk mencegah kebosanan para pengunjung ketika berada di dalamnya.

h. A home away from home

Memberikan kesan dan kehangatan yang sama dengan rumah yang sebenarnya.

\section{"Happy City" oleh Charles Montgomery}

Montgomery (2013) dalam bukunya yang berjudul "Happy City: transforming our lives through urban design" mengatakan bahwa untuk menjadi dekat dengan satu sama lain, kita (manusia) membutuhkan jarak dengan satu sama lain, ditambah dengan sentuhan alam - namun tetap pada porsinya. Selain itu, dikatakan pula, berdasarkan penelitian, orang-orang yang tinggal dekat dengan ruang terbuka hijau lebih mengenal tetangganya dibandingkan mereka yang tidak. Dalam bab ini, Montgomery juga mengingatkan, bertemu dengan terlalu banyak orang asing ataupun berada di antara keramaian dapat menjengkelkan bagi beberapa orang. Selain itu, kehidupan kota, sebagaimana dirasakan oleh Milgram, menuntut seseorang untuk menciptakan sebuah jarak, sehingga keramaian kota pada dasarnya tidak mendorong manusia untuk saling mendekat, sebaliknya justru membuat manusia saling berjauhan. Menurutnya, tempat yang kita butuhkan adalah tempat yang mampu mewadahi interaksi kita dengan orang asing tanpa harus 'mundur' sepenuhnya.

\section{"Integral Urbanism" oleh Nan Ellin}

Ellin (2006) dalam bukunya yang berjudul "Integral Urbanism" menjelaskan mengenai bagaimana pergerakan manusia dan masyarakat saat ini tidak lagi harus terkotak-kotak. Untuk menciptakan sebuah urbanisme integral, terdapat 5 karakteristik:

a. Hybridity \& Connectivity

Hibriditas dan konektivitas ini pada dasarnya membawa aktivitas dan manusia menjadi satu, bukannya memisahkan fungsi dan objektivitas. Manusia dan alam adalah sesuatu yang saling bersimbiosis dan mempengaruhi, bukan berlawanan.

b. Porosity

Menghilangkan batasan-batasan, salah satunya dengan permeable membranes yang memungkinkan akses fleksibel. 


\section{c. Authenticity}

Authenticity atau keaslian merupakan hasil pemikiran yang berdasarkan pada kondisi fisik dan sosial pada dunia nyata. Seiring dengan waktu, hal ini nantinya akan terus berkembang dan berubah sesuai dengan kebutuhan yang ada.

d. Vulnerability

\section{"Architecture and Disjunction" oleh Bernard Tschumi}

Tschumi (1994) di dalam bukunya yang berjudul "Architecture and Disjunction", mengemukakan tentang adanya sebuah konsep Transprogramming dan Crossprogramming. Transprogramming yang disebutkan oleh Bernard Tschumi menggabungkan dua program yang berbeda di dalam bangunan yang sama, walaupun secara spasial tidak sesuai satu dengan yang lain. Sebagai contoh, perpustakaan yang digunakan sebagai arena balap. Sedangkan crossprogramming yaitu menggunakan ruang atau konfigurasi spasial yang tidak sesuai dengan program asalnya. Sebagai contoh, bangunan ibadah yang digunakan sebagai klub malam. Konsep ini sendiri meliputi dua aspek, aktivitas yang harus bisa tumpang tindih, dan bangunan yang bisa beradaptasi dengan program yang berbeda dari waktu ke waktu.

\section{METODE}

\section{Pengumpulan Data}

Data primer

Penulis melakukan studi lapangan dengan melakukan pengamatan langsung pada lokasi. Pengamatan dilakukan terhadap kondisi fisik kawasan dan aktivitas masyarakat sehari-hari dan didokumentasikan secara pribadi. Kemudian, penulis mewawancarai penduduk setempat secara non-formal sebagai informasi tambahan dalam penelitian mengenai aktivitas sehari-hari dan kegiatan rutin bulanan maupun tahunan penduduk setempat. Untuk data kependudukan, penulis mengajukan permintaan pada kantor kelurahan setempat untuk mendapatkan data kependudukan terbaru secara lengkap mengenai jumlah penduduk dalam segi usia, pekerjaan, mobilitas, agama, dll. Dari hasil pengumpulan data, penulis berusaha mengarah pada isu sosial yang terdapat di dalam kawasan, kemudian mulai merumuskan masalah dalam bentuk potensi dan permasalahan yang dapat dikembangkan menjadi ide program dan rencana rancangan desain bangunan.

\section{Data sekunder}

a. Studi literatur

b. Studi literatur berupa buku, jurnal, dan internet untuk menambah data dalam perancangan Ruang Hijau Alternatif, baik dalam usaha menyelesaikan isu kawasan ataupun dalam menetapkan rencana perancangan.

c. Studi preseden

d. Studi preseden sebagai pembelajaran dan penggambaran visualisasi dalam rencana perancangan terkait dengan tampilan fisik bangunan yang sesuai dengan kriteria third place.

\section{Perencanaan}

Dalam perencanaan digunakan metode analisis-sintesis. Hal ini dilakukan dengan menganalisis kawasan, yang kemudian menghasilkan program kegiatan untuk mewadahi aktivitas-aktivitas yang ada di kawasan. Selain itu digunakan pula pendekatan dengan teori critical regionalism. Di mana teori ini dipengaruhi oleh kebutuhan dan karakteristik dari lokasi tersebut. Kemudian, secara keseluruhan teori ini terkait dengan keterhubungan suatu bangunan dengan tempat (Canizaro 2007:17-18). Dalam perancangan ruang, untuk menciptakan sebuah ruang yang 
fleksibel dan saling terhubung satu dengan yang lain, menggunakan konsep crossprogramming dan transprogramming.

\section{DISKUSI DAN HASIL}

\section{Analisis Lokasi}

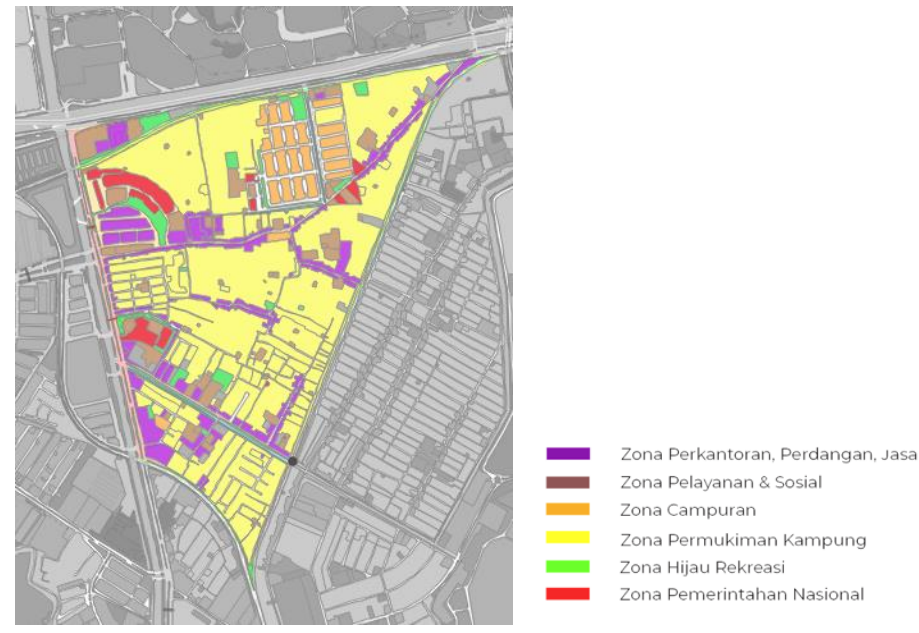

Gambar 1. Peta Penggunaan Lahan Kelurahan Pademangan Barat Sumber: jakartasatu.jakarta.go.id, 2020

Kawasan terpilih yaitu Kelurahan Pademangan Barat yang merupakan salah satu kelurahan terpadat di Jakarta. Terletak di Kecamatan Pademangan, Jakarta Utara, kelurahan ini secara keseluruhan didominasi oleh permukiman penduduk dengan kelas perekonomian menengah ke bawah. Selain itu, karena padatnya permukiman penduduk, ruang terbuka hijau pada kawasan ini tidak mencapai $30 \%$ dari keseluruhan luas wilayah. Dari segi penduduk, secara umum, masyarakat di Kelurahan Pademangan sudah terbiasa dengan aktivitas yang mengandalkan jalan kaki, mengingat banyaknya gang-gang sempit yang tidak memungkinkan untuk penggunaan kendaraan beroda empat. Kendaraan paling umum di dalam gang-gang kecil ini adalah motor dan sepeda. Selain itu, kendaraan umum seperti becak dan bajaj juga menjadi salah satu alternatif untuk warga.

Berdasarkan hasil pengamatan, warga di Pademangan cenderung mengenal tetangga sekitar dan sering berinteraksi satu sama lain. Hal ini didorong oleh padatnya bangunan dan ruas-ruas jalan yang cukup sempit, di mana banyak gang yang tidak dapat dilalui kendaraan bermotor sehingga memaksa warga untuk berjalan kaki dan mendorong terciptanya interaksi antar tetangga. Selain itu, banyaknya penduduk yang berjualan di sekitar tempat tinggal juga memungkinkan interaksi ini terjadi.
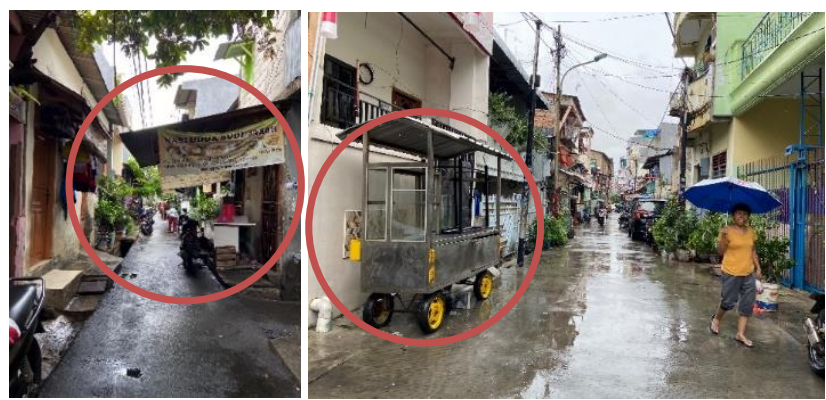

Gambar 2. Masyarakat Berjualan di Kawasan Sumber: Dokumentasi Pribadi, 2020 
Dari permukiman ini juga dapat terlihat ketertarikan masyarakat dalam melakukan penghijauan di depan rumah masing-masing, baik berupa tanaman di dalam pot, ataupun dalam bentuk hidroponik. Hal ini menunjukkan adanya kesadaran masyarakat mengenai kurangnya penghijauan dalam keterbatasan lahan yang ada.

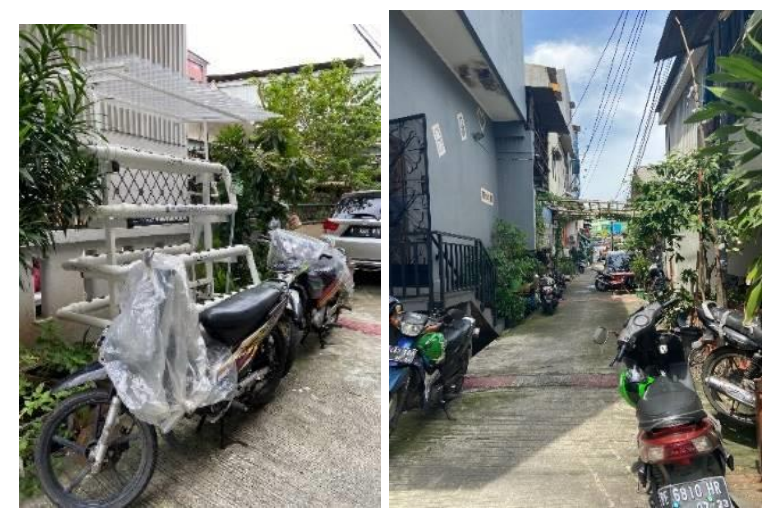

Gambar 3. Masyarakat Menanam Tanaman di Depan Rumah Sumber: Dokumentasi Pribadi, 2020
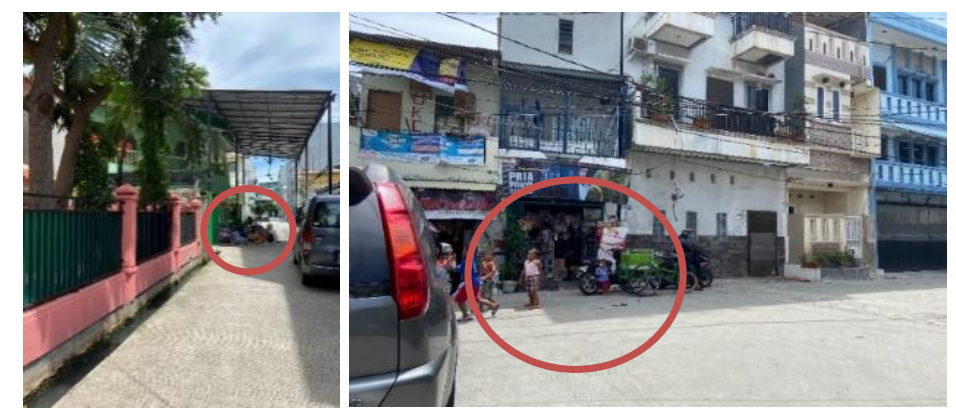

Gambar 4. Interaksi Anak-anak dan Ibu-ibu di Jalanan Sumber: Dokumentasi Pribadi, 2020

Berdasarkan hasil analisis dan pengamatan pada kawasan, berikut beberapa potensi dan permasalahan yang ada di Kelurahan Pademangan Barat.

Tabel 1. Potensi dan Permasalahan di Kawasan

\begin{tabular}{|c|c|}
\hline POTENSI & PERMASALAHAN \\
\hline Adanya Kampung Sehat & $\begin{array}{l}\text { Minimnya penghijauan \& ruang terbuka } \\
\text { untuk aktivitas bersama, salah satunya } \\
\text { disebabkan karena terbatasnya lahan yang } \\
\text { ada }\end{array}$ \\
\hline $\begin{array}{l}\text { Ketertarikan masyarakat melakukan } \\
\text { penghijauan sendiri terlihat di depan rumah } \\
\text { masing-masing }\end{array}$ & $\begin{array}{l}\text { Pemanfaatan jalanan sebagai ruang publik: } \\
\text { - } \quad \text { Anak-anak banyak bermain di } \\
\text { pinggir jalanan } \\
\text { - } \quad \text { Perayaan } 17 \text { Agustus pada ruang } \\
\text { jalan } \\
\text { - } \quad \text { Senam pagi setiap hari Minggu } \\
\text { - } \text { Tenda-tenda kuliner pk. } 17.00\end{array}$ \\
\hline
\end{tabular}

Banyaknya masyarakat yang berjualan di dalam kawasan

Sumber: Penulis, 2020 


\section{Ide Program}

Berdasarkan data dan analisis kawasan yang ada, serta didasarkan pada potensi dan permasalahan yang ada pada kawasan, berikut beberapa ide program.

Tabel 2. Ide Program

\begin{tabular}{|c|c|c|c|c|}
\hline & $\begin{array}{c}\text { Sarana Edukasi } \\
\text { dan } \\
\text { Pengembangan } \\
\text { Penghijauan }\end{array}$ & Temporary Space & $\begin{array}{c}\text { Sarana Belajar \& } \\
\text { Bermain Untuk } \\
\text { Anak-anak }\end{array}$ & Culinary \\
\hline$\underset{3}{z}$ & $\begin{array}{l}\text { Mengembangkan } \\
\text { potensi masyarakat }\end{array}$ & $\begin{array}{l}\text { Menggantikan } \\
\text { fungsi jalan } \\
\text { sebagai ruang } \\
\text { publik }\end{array}$ & $\begin{array}{l}\text { Mewadahi } \\
\text { kegiatan dan } \\
\text { aktivitas anak- } \\
\text { anak sepulang } \\
\text { sekolah }\end{array}$ & $\begin{array}{l}\text { Untuk } \\
\text { mendukung minat } \\
\text { masyarakat dalam } \\
\text { berdagang } \\
\text { terutama dalam } \\
\text { bidang kuliner }\end{array}$ \\
\hline \multirow{5}{*}{ 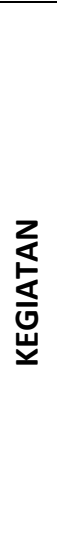 } & $\begin{array}{l}\text { Edukasi mengenai } \\
\text { penghijauan }\end{array}$ & $\begin{array}{l}\text { Perayaan hari raya } \\
\text { seperti } 17 \text { Agustus }\end{array}$ & Mini Library & $\begin{array}{l}\text { Sarana berdagang } \\
\text { untuk masyarakat }\end{array}$ \\
\hline & $\begin{array}{l}\text { Taman Obat } \\
\text { Keluarga }\end{array}$ & $\begin{array}{l}\text { Senam pagi } \\
\text { Bersama setiap } \\
\text { minggu }\end{array}$ & $\begin{array}{l}\text { Area bermain } \\
\text { anak }\end{array}$ & \\
\hline & Mini Composting & $\begin{array}{l}\text { Kegiatan bulanan } \\
\text { dari kelurahan }\end{array}$ & & \\
\hline & $\begin{array}{l}\text { Workshop } \\
\text { pengolahan hasil } \\
\text { bercocok tanam }\end{array}$ & $\begin{array}{l}\text { Aktivitas temporer } \\
\text { spontan lainnya } \\
\text { yang } \\
\text { memungkinkan }\end{array}$ & & \\
\hline & $\begin{array}{l}\text { Pertokoan terkait } \\
\text { penghijauan }\end{array}$ & & & \\
\hline
\end{tabular}

Sumber: Penulis, 2020

Pemrograman aktivitas ini dilengkapi dengan beberapa teori pendukung, yakni teori dari Bernard Tschumi mengenai transprogramming dan crossprogramming yang nantinya dapat diterapkan dalam perancangan ruang di dalam bangunan.

\section{Pemilihan Tapak \& Proses Gubah}

Ada beberapa kriteria dalam menentukan lokasi tapak. Kriteria pemilihan tapak dalam proyek ini adalah

a. Dapat dijangkau oleh pejalan kaki dari moda transportasi Transjakarta;

b. Dapat dijangkau oleh pejalan kaki dari SAMSAT yang sering dijadikan tempat berkumpul bagi masyarakat;

c. Berada di lingkungan yang tidak terlalu padat;

d. Mudah diakses oleh warga sekitar; dan

e. Berada di jalan yang terkenal dengan kuliner Seafood. 


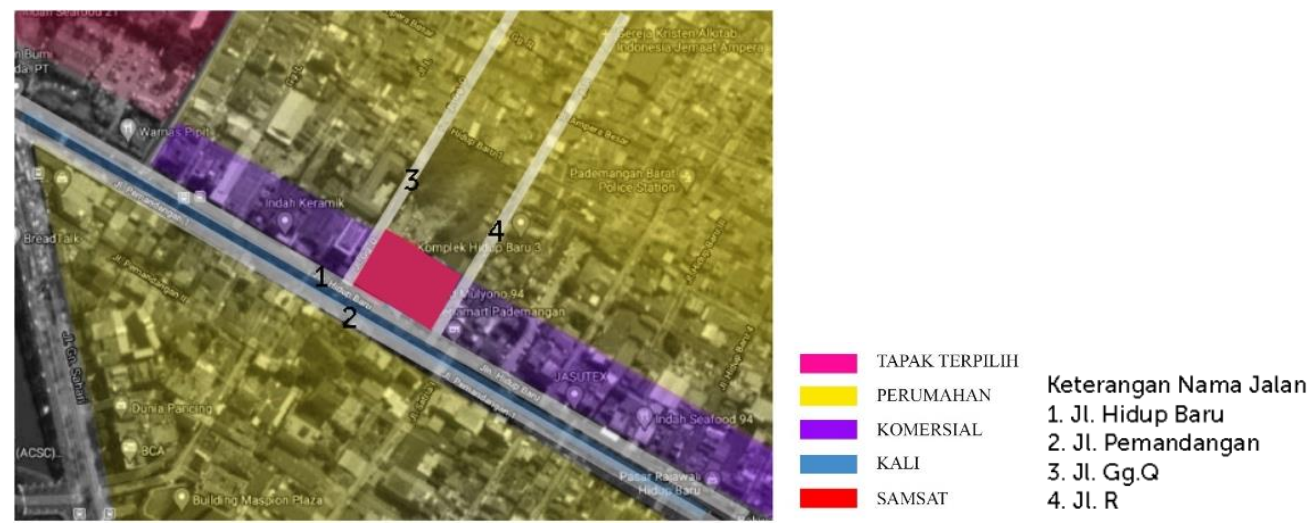

Gambar 5. Tapak terpilih di Jl. Hidup Baru

Sumber: Dokumentasi Pribadi, 2020
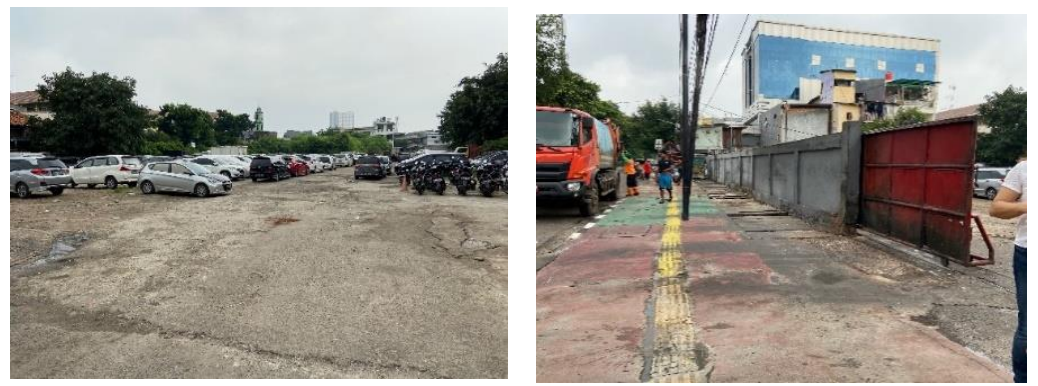

Gambar 6. Kondisi Fisik Tapak Terpilih

Sumber: Dokumentasi Pribadi, 2020

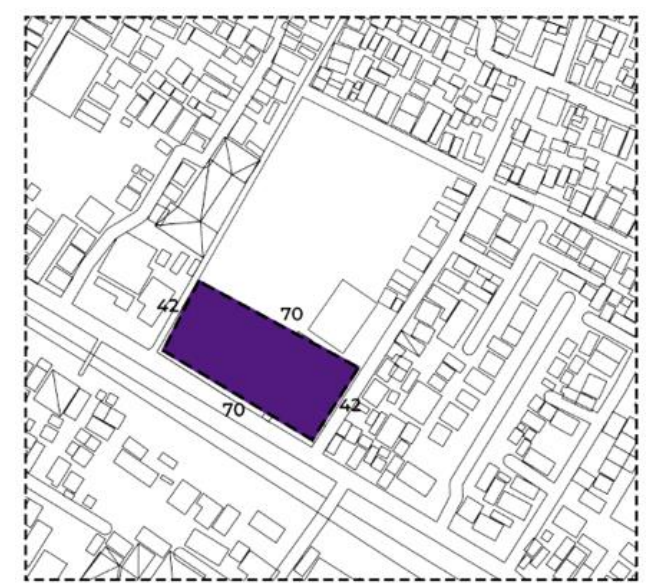

LOKASI

JL. Hidup Baru, Kelurahan Pademangan Barat, Kecamatan Pademangan

$\begin{array}{ll}\text { LUAS TAPAK } & 2940 \mathrm{M} 2 \\ \text { KDB } & 60 \\ \text { KLB } & 2.4 \\ \text { KB } & 4 \\ \text { KDH } & 30\end{array}$

Gambar 7. Data Tapak

Sumber: Dokumentasi Pribadi, 2020

Tapak memiliki akses yang baik, baik dari segi pejalan kaki maupun dengan kendaraan umum. Selain itu, tapak ini juga berada di depan jalan yang memiliki mobilitas lalu lintas yang tinggi sehingga dapat menarik pengunjung dari luar kawasan. 


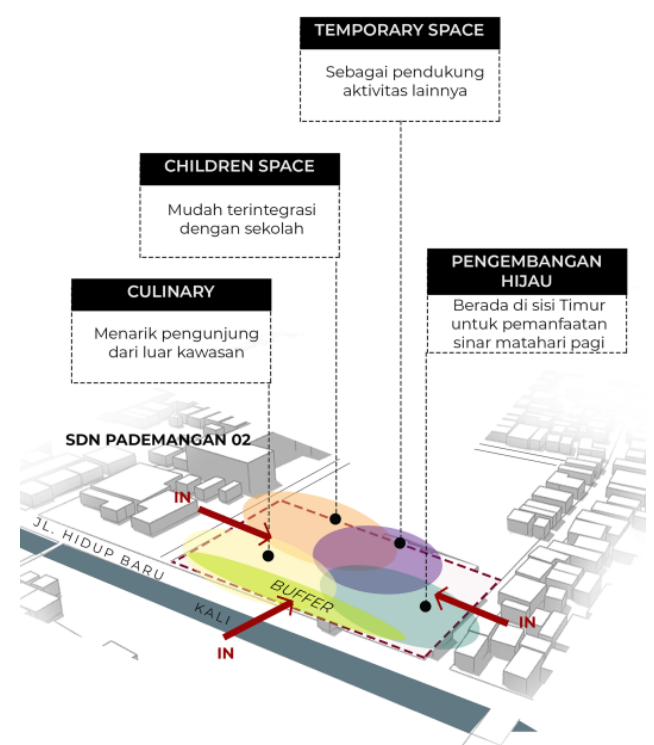

Gambar 8. Zoning Tapak Berdasarkan Analisis Sumber: Dokumentasi Pribadi, 2020

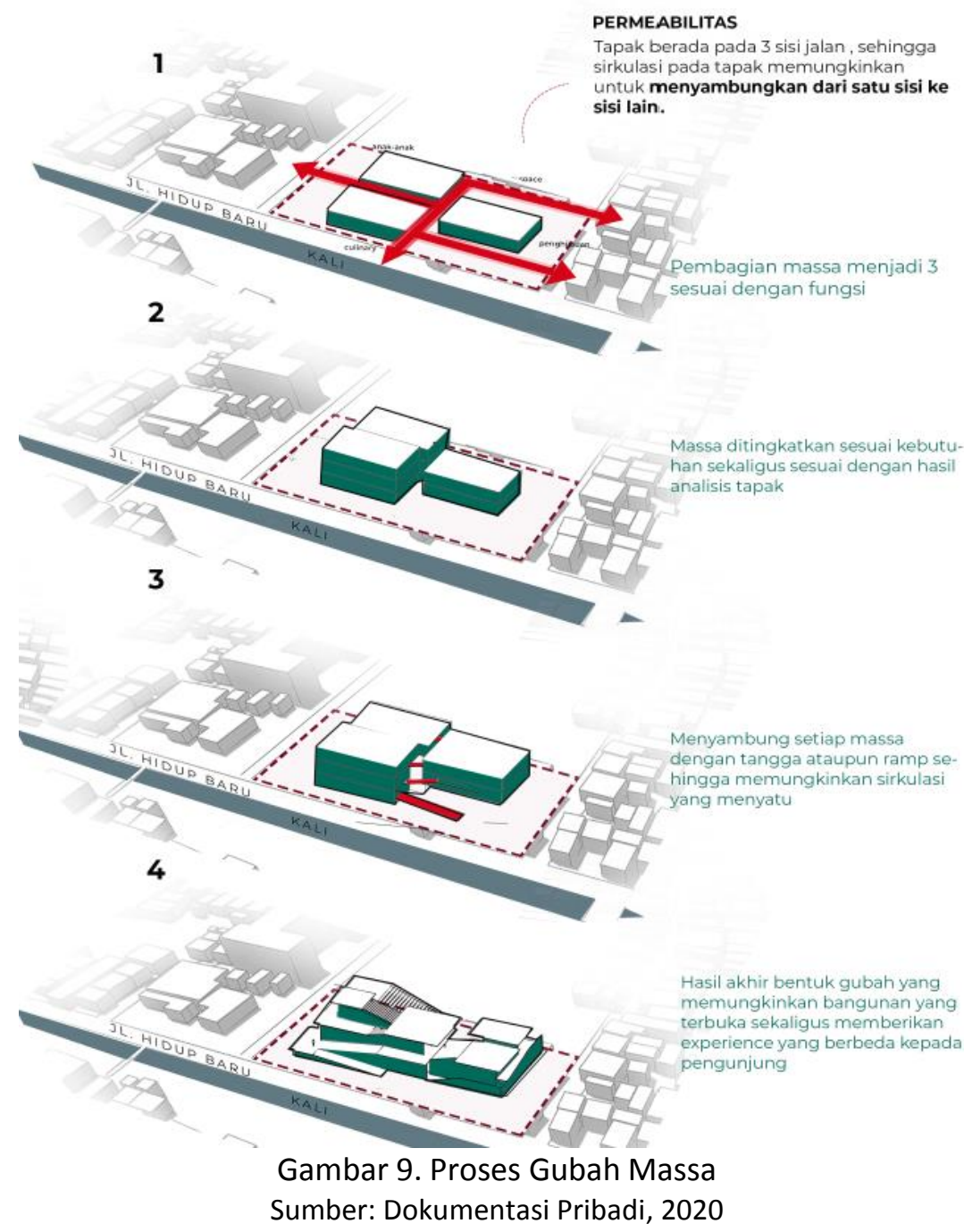




\section{Rencana Perancangan}

Rencana rancangan awal bangunan didasarkan pada beberapa kriteria third place dari Ray Oldenburg, yaitu neutral ground, low profile, leveler, accessibility \& accomodity, dan the regulars.

Selain itu, didasarkan dari lingkungan kawasan, berikut beberapa kriteria rancangan:

a. Memberikan kesan ringan dan transparansi

Kesan ringan pada bangunan untuk memberikan kesan yang berbeda dari kawasan yang cenderung padat. Sedangkan transparansi memungkinkan visualisasi aktivitas dari luar bangunan ke dalam dan begitu pun sebaliknya sehingga memberikan kesan keterbukaan dan dapat menarik pengunjung.

b. Memberikan kesan unpretentious pada tampilan bangunan

Kesan unpretentious dengan penggunaan material-material yang tidak memberikan kesan mewah. Hal ini untuk mengimbangi lingkungan sekitar yang didominasi permukiman penduduk yang padat dan berada di lingkungan dengan perekonomian kelas menengah ke bawah.

c. Peil yang ditinggikan

Peil bangunan yang ditinggikan ini untuk mengantisipasi adanya potensi banjir pada kawasan.

\section{Deskripsi Design}

Salah satu rencana rancangan desain yang didasari dari kondisi kawasan adalah untuk memberikan kesan ringan pada bangunan. Kesan ringan pada bangunan ini pada akhirnya divisualisasikan dengan penggunaan rangka dan meminimalisir penggunaan dinding masif. Selain itu, penggunaan rangka ini juga untuk memaksimalkan pencahayaan dan pengudaraan alami pada bangunan. Kemudian rangka-rangka ini juga dilengkapi dengan tanaman rambat untuk menambah nilai estetika sekaligus memberikan kesan 'hijau' baik dari luar bangunan maupun dalam bangunan.
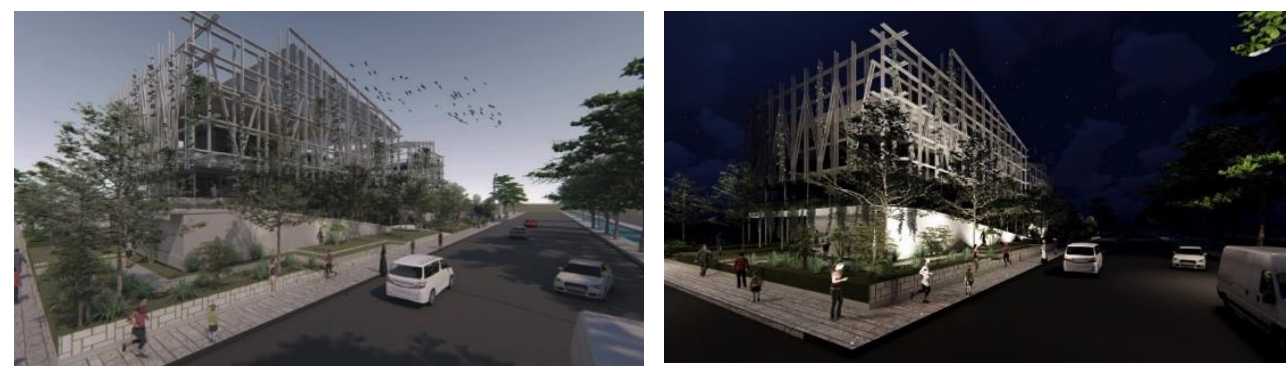

Gambar 10. Perspektif Eksterior

Sumber: Dokumentasi Pribadi, 2020

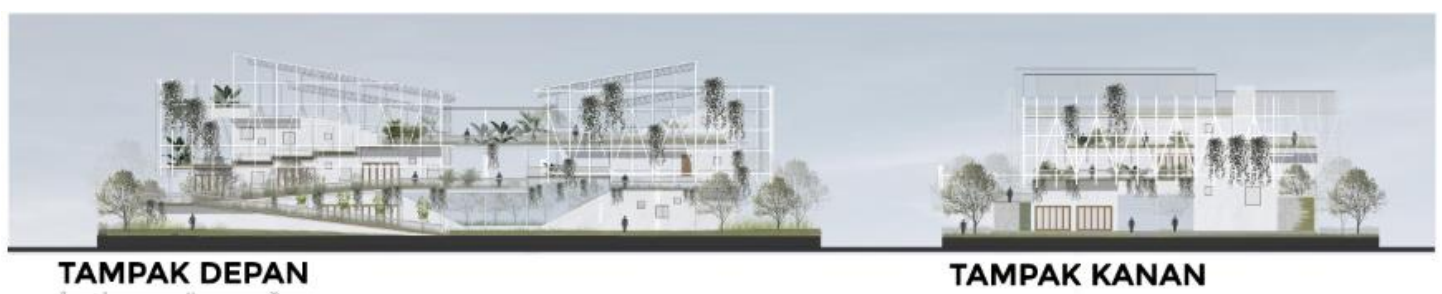




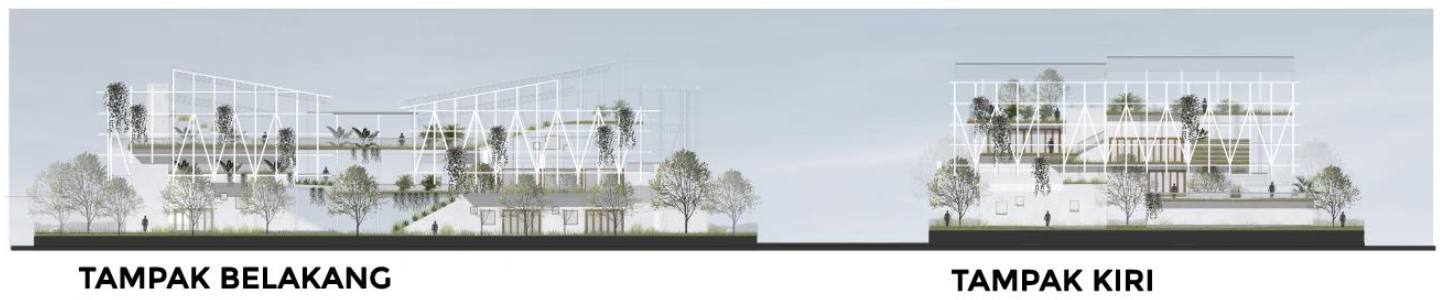

Gambar 11. Tampak Eksterior Bangunan

Sumber: Dokumentasi Pribadi, 2020

Dari segi interior, denah pada bangunan dibuat fleksibel dan terbuka dengan batasan secukupnya pada tiap fungsi, terutama pada denah lantai 1 yang memungkinkan visual pada aktivitas di dalam bangunan dan juga memungkinkan permeabilitas dari satu sisi tapak ke sisi tapak lainnya. Kemudian, tiap fungsi juga saling terkait satu dengan yang lain dengan ruangruang fleksibel dan berdampingan. Dengan fungsi edukasi dan pengembangan penghijauan alternatif, unsur hijau berupa tanaman-tanaman menjadi elemen penting yang dapat ditemukan pada segala sisi bangunan.

Warna netral dari penggunaan material beton dan dinding bata untuk mengimbangi warna hijau agar menjadi elemen utama pada bangunan, sekaligus tidak menghadirkan kesan mewah di dalamnya.
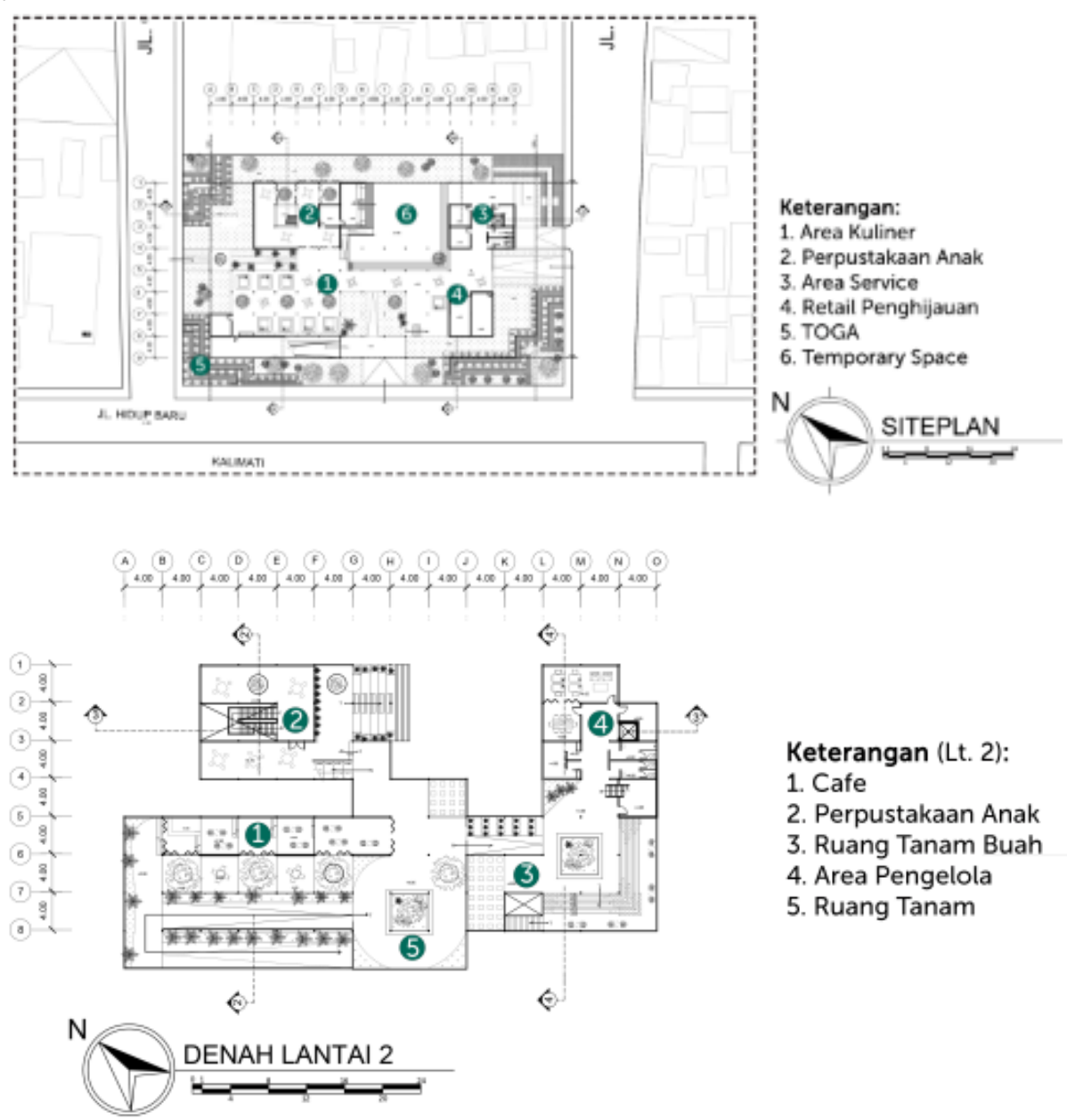
Keterangan (Lt. 3):

1. Ruang Tanam Tanaman Hias

2. Ruang Serbaguna

3. Ruang Media

4. Ruang Hidroponik
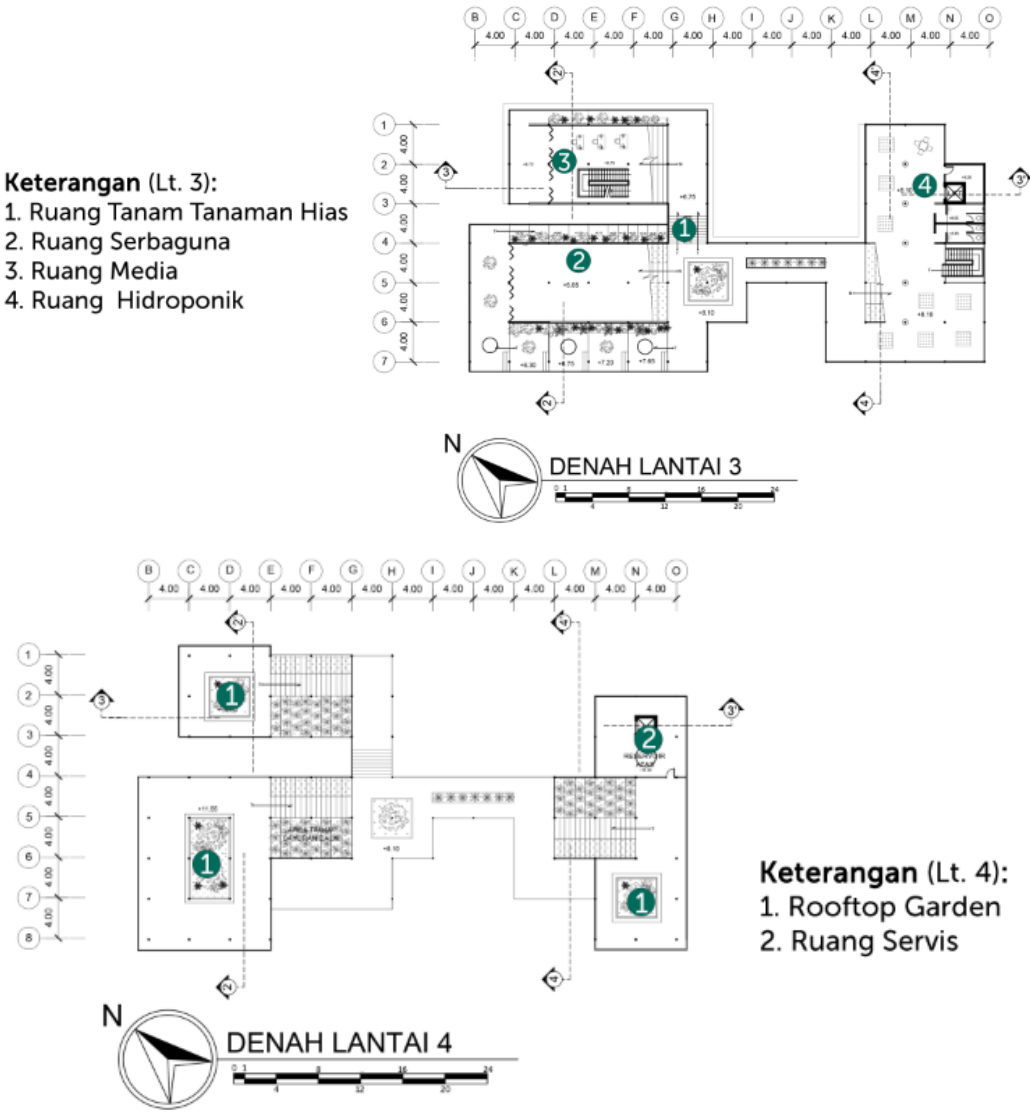

Gambar 12. Denah Ruang Hijau Alternatif Pademangan

Sumber: Dokumentasi Pribadi, 2020

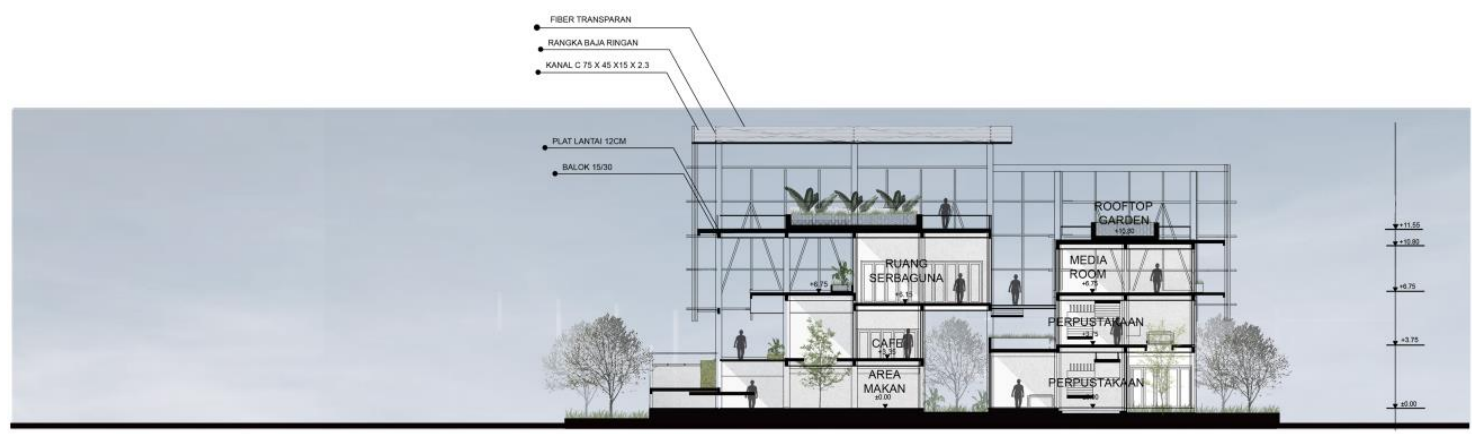

POTONGAN 2-2'

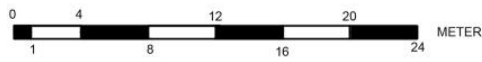

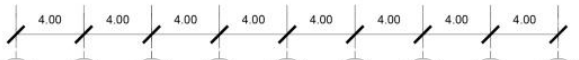

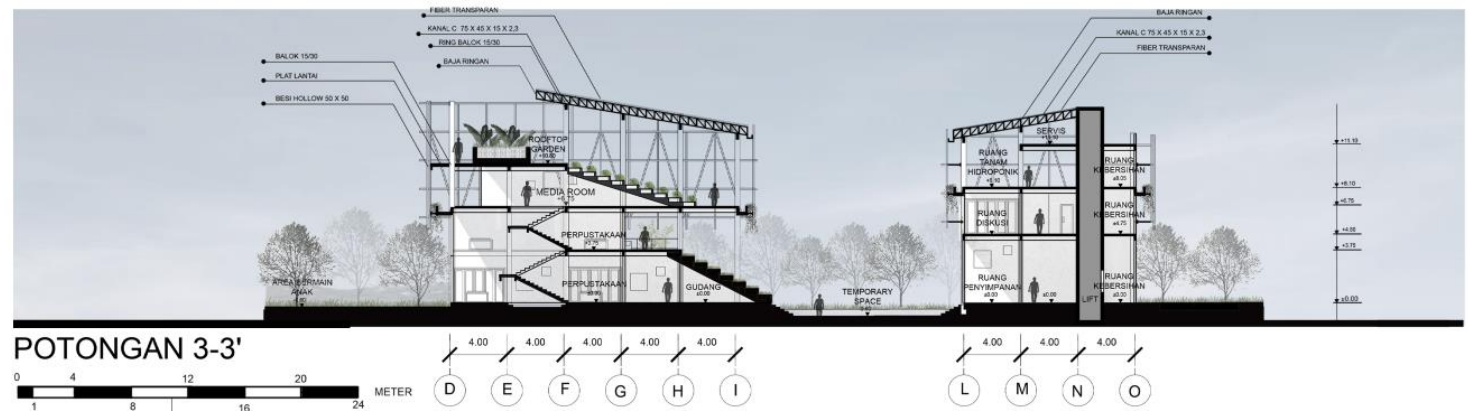

Gambar 13. Potongan Ruang Hijau Alternatif Pademangan

Sumber: Dokumentasi Pribadi, 2020 

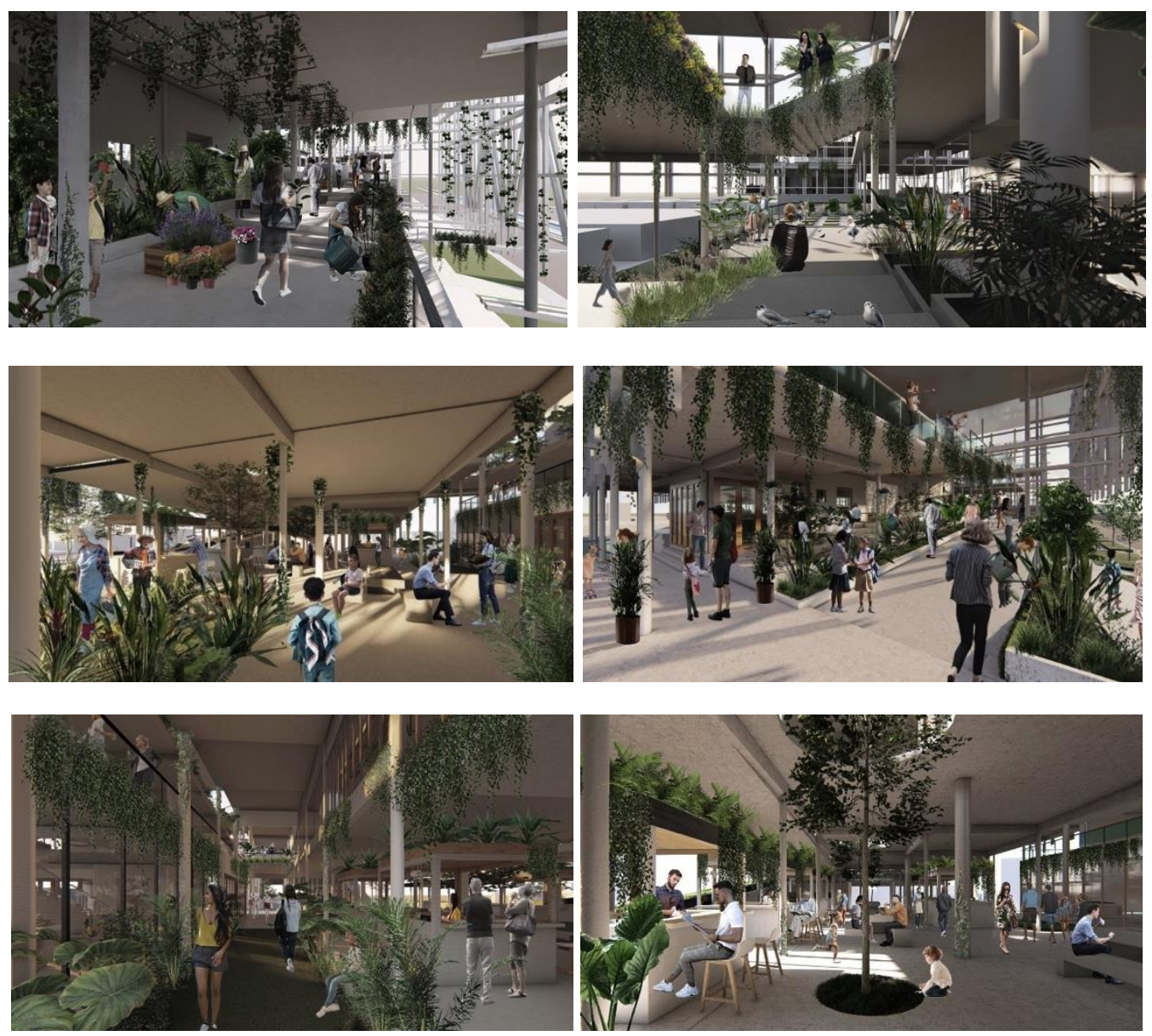

Gambar 14. Perspektif Interior Ruang Hijau Alternatif

Sumber: Dokumentasi Pribadi, 2020

\section{KESIMPULAN DAN SARAN}

Dengan konsep keterbukaan dan transparansi, serta didasarkan atas konsep third place yang diperkenalkan oleh Ray Oldenburg, juga beberapa teori pendukung lainnya, bangunan ini diharapkan dapat menjadi sebuah wadah yang bermanfaat untuk masyarakat. Terlepas dari fokus utamanya yang ditujukan untuk masyarakat sekitar, bangunan ini diharapkan juga mampu menarik pengunjung dari luar kawasan dan menjadikannya sebuah ruang publik yang nyaman untuk semua kalangan. Dengan adanya third place ini, diharapkan pengunjung dapat saling berinteraksi satu dengan yang lain, bersosialisasi, sekaligus melakukan aktivitas yang bermanfaat, baik untuk peningkatan kualitas hidup secara individual maupun dalam lingkup kawasan. Melihat adanya keterbatasan lahan dengan fungsi publik, pada dasarnya bangunan ini berusaha untuk menjadi wadah yang mampu menampung beragam potensi aktivitas masyarakat. Saran penulis, diharapkan, ke depannya, proyek ini dan proyek-proyek lainnya yang serupa dapat menjadi pembelajaran dalam memenuhi kebutuhan masyarakat setempat, terutama dalam hal peningkatan kualitas hidup. Selain itu, pentingnya aktivitas secara sosial yang memungkinkan interaksi antar individu sekaligus dengan elemen hijau di dalamnya dapat dipertimbangkan sebagai opsi untuk mendukung peningkatan kawasan menjadi lebih baik.

\section{REFERENSI}

Canizaro,V. (2007). Architectural Regionalism: Collected Writings on Place, Identity, Modernity, and Tradition. Princeton Architectural Press.

Elin, N. (2006). Integral Urbanism. New York: Routledge.

https://jakartasatu.jakarta.go.id/ 
Montgomery, C. (2013). Happy City: transforming our lives through urban design. First edition. New York: Farrar, Straus and Giroux.

Oldenburg, R. (1997). The Great Good Place. Cambridge: Da Capo Press.

Tschumi, B. (1994). Architecture and Disjunction. Cambridge: MIT Press. 